\title{
Origin and Evolution of the Ribosome
}

\author{
George E. Fox \\ Department of Biology and Biochemistry, University of Houston, Houston, Texas 77204-5001 \\ Correspondence: fox@uh.edu
}

The modern ribosome was largely formed at the time of the last common ancestor, LUCA. Hence its earliest origins likely lie in the RNA world. Central to its development were RNAs that spawned the modern tRNAs and a symmetrical region deep within the large ribosomal RNA, (rRNA), where the peptidyl transferase reaction occurs. To understand pre-LUCA developments, it is argued that events that are coupled in time are especially useful if one can infer a likely order in which they occurred. Using such timing events, the relative age of various proteins and individual regions within the large rRNA are inferred. An examination of the properties of modern ribosomes strongly suggests that the initial peptides made by the primitive ribosomes were likely enriched for L-amino acids, but did not completely exclude D-amino acids. This has implications for the nature of peptides made by the first ribosomes. From the perspective of ribosome origins, the immediate question regarding coding is when did it arise rather than how did the assignments evolve. The modern ribosome is very dynamic with tRNAs moving in and out and the mRNA moving relative to the ribosome. These movements may have become possible as a result of the addition of a template to hold the tRNAs. That template would subsequently become the mRNA, thereby allowing the evolution of the code and making an RNA genome useful. Finally, a highly speculative timeline of major events in ribosome history is presented and possible future directions discussed.

\begin{abstract}
A major commonality of all cellular life is Athe coupling between translation and transcription mediated by the genetic code. Comparative genomics has further refined this by revealing the presence of an "RNA metabolism" (Anantharaman et al. 2002) or "Persistent proteome" (Danchin et al. 2007) that is basically a compendium of essentially universal genes involved in translation, transcription, RNA processing and degradation, intermediary and RNA metabolism, and compartmentalization. DNA replication likely arose later because the
\end{abstract}

core enzymes involved in the process are not related (Bailey et al. 2006 and others). Together these universal genes comprise what is frequently referred to as LUCA, the last universal common ancestor (Benner et al. 1993; Lazcano 1994; Mushegian and Koonin 1996; Kyrpides et al. 1999). It is noteworthy that no matter how they are defined, by far the largest numbers of genes in LUCA are associated with translation. Indeed, the translation machinery as represented in LUCA is essentially complete indicating that major events in its origins

Editors: David Deamer and Jack W. Szostak

Additional Perspectives on The Origins of Life available at www.cshperspectives.org

Copyright (C) 2010 Cold Spring Harbor Laboratory Press; all rights reserved; doi: 10.1101/cshperspect.a003483

Cite this article as Cold Spring Harb Perspect Biol 2010;2:a003483 


\section{G.E. Fox}

occurred before LUCA. Thus, it might appear that the origins of the translation machinery would be hopelessly obscured by time. Nevertheless, as will be discussed herein, substantial although necessarily incomplete, evidence relating to the origins and early development of the translation machinery and its relation to other core cellular processes continues to exist in the primary sequences, three-dimensional folding, and functional interactions of the various macromolecules involved in the modern versions of the translation machinery.

The modern ribosome consists of small and large subunits (30S and 50S in Bacteria and Archaea) that come together during the initiation of protein synthesis remain together as individual amino acids are added to a growing peptide according to information encoded on the mRNA, and finally separate again in conjunction with the release of the finished protein. Each subunit is an RNA/protein complex. In Bacteria and Archaea, the 50S subunit typically contains a $23 \mathrm{~S}$ rRNA and a 5S rRNA whereas the $30 \mathrm{~S}$ subunit contains the $16 \mathrm{~S}$ rRNA. Peptide bond synthesis occurs in the 50S subunit at the peptidyl transferase center, (PTC), and codon recognition occurs at the decoding site, which is in the small subunit. Transfer RNAs, (tRNA), bridge the two subunits occupying, at various times in the synthesis cycle, the $\mathrm{A}, \mathrm{P}$, or $\mathrm{E}$ (exit) sites of the $50 \mathrm{~S}$ subunit and the decoding site in the $30 \mathrm{~S}$ subunit. A universal CCA sequence at the $3^{\prime}$ end of the tRNA is the point of attachment of the amino acid and later the growing peptide chain to the tRNA. The A, P, and $\mathrm{E}$ sites are partly in the small subunit and partly in the large subunit such that a tRNA can be in a hybrid site (e.g., the A site in the $30 \mathrm{~S}$ and $\mathrm{P}$ site in the 50S. The mRNA is exclusively found in the small subunit where it interacts with the anticodon loops of the tRNAs. As the nascent protein is synthesized it passes through an exit tunnel that begins at the PTC center and ultimately exits from the back of the 50 S subunit. Synthesis is a dynamic cyclic process in which tRNAs enter the ribosome bringing amino acids as specified by the mRNA and move through the machinery, which undergoes a series of coordinated motions that drive the process (Steitz 2008). These include the movements of the tRNAs between sites, opening and closing of the L1 stalk on the $50 \mathrm{~S}$ subunit and the ratcheting of the small subunit relative to the large subunit (Frank and Agrawal, 2000), which has recently been elucidated in structural detail (Zhang et al. 2009).

Diverse species (Escherichia coli, Haloarcula marismortui, Thermus thermophiles, and Deinococcus radiodurans) are represented among the various atomic resolution ribosome structures now available (Ban et al. 2000; Yusupov et al. 2000; Wimberly et al. 2000; Schuwirth et al. 2005; Selmer et al. 2006; and others). These structures encompass $30 \mathrm{~S}$ and $50 \mathrm{~S}$ subunits as well as the whole $70 \mathrm{~S}$ ribosome. In addition, cryoelectron microscopy studies have revealed dynamic motions associated with the ribosome (Frank and Agrawal 2000; Connell et al. 2007; and others). These ongoing high resolution structural studies provide the opportunity to examine the relative age of features within the ribosome such as the $\mathrm{A}, \mathrm{P}$, and $\mathrm{E}$ sites, the exit tunnel, the $\mathrm{L} 7 / \mathrm{L} 12$ region, and the $\mathrm{L} 1$ region that facilitate the entry and exit of tRNAs.

\section{PEPTIDYL TRANSFERASE CENTER}

It is believed that the peptidyl transferase center, (PTC), which encompasses the large subunit portions of the $\mathrm{A}$ and $\mathrm{P}$ sites of the ribosome, is structurally the same in both the $50 \mathrm{~S}$ and $70 \mathrm{~S}$ subunits (Steitz 2008). When comparing 50S subunit structures between Archaea and Bacteria one again finds that the structures are essentially the same. However, the E site structure is different. In Archaea L44e interacts with the E-site tRNA but this protein is missing in Bacteria with the result that the tRNA CCA end is positioned differently. Hence, the A and $\mathrm{P}$ sites likely predate the E site, which may have been added post-LUCA (Steitz 2008).

The portion of $23 \mathrm{~S}$ rRNA comprising the PTC contains a region of approximately 165 bases that shows high twofold pseudo symmetry (Agmon et al. 2005; Zimmerman \& Yonath 2009). The two 82 nucleotide halves of the symmetrical region correspond to the $50 \mathrm{~S}$ portion of the $\mathrm{A}$ and $\mathrm{P}$ sites of the ribosome. In fact, 
the essence of this region is contained in a single contiguous self-folding RNA (Smith et al. 2008). The PTC is located in Domain 5 of the $23 \mathrm{~S}$ rRNA structure.

Recently, Hsiao et al. (2009) superimposed the structure of the large subunit RNAs from two ribosome crystal structures and sectioned the resulting structure into concentric shells with the PTC at the center. They, like others (Ban et al. 2000; Wimberly et al. 2000), found that ribosomal proteins (r-proteins) are effectively absent from the PTC region, which is why the ribosome is regarded as fundamentally an RNA machine. To the extent that protein elements are in proximity to the PTC, they are short, largely unstructured peptides rather than globular elements. The globular regions are mainly on the surface of the ribosome (Ban et al. 2000; Wimberly et al. 2000). A major stabilizing element in the PTC region is instead $\mathrm{Mg}^{2+}$ interactions. In many cases, the phosphate oxygen atoms act as inner sphere $\mathrm{Mg}^{2+}$ ligands (Hsiao et al. 2009; Hsiao and Williams 2009). Thus, consistent with the notion of a preceding RNA world, the structure of the PTC seems to have evolved before the availability of proteins.

Although the modern translation machinery is very complex, two small RNAs, the PTC RNA fragment and tRNAs are at its core. Both of these are less than 100 nucleotides in length, and their importance supports the notion that the translation machinery was originally a discovery of the RNA world. In fact, the ability to synthesize coded peptides of increasing complexity would eventually terminate the RNA world and create the RNA/protein world. The seldom discussed issue is whether such a termination would have occurred before (e.g., brief RNA world) or after the discovery of an RNA replicase (extended RNA world). If peptide synthesis arises quickly, then their will neither be time nor need for extensive catalysis of biochemical reactions by RNA. If reasonable, the rapid appearance of a translation system may even eliminate the need to validate the RNA world by demonstrating the self-replicating RNA system that has proven experimentally difficult to achieve.

\section{tRNA ORIGINS AND INCREASING RNA COMPLEXITY}

Because of its obvious importance, considerable attention has been focused on the origins of the tRNA and numerous models have been proposed and recently reviewed (Di Giulio 2009). The most popular model (Noller 1993; Maizels and Weiner 1993 and 1994; Schimmel et al. 1993; Schimmel and Henderson 1994), envisions the tRNA as having two domains, each encompassing half the molecule. One domain contains the terminal CCA sequence to which the incoming amino acid or growing peptide is attached. The second domain contains the anticodon and associated loop that interact with the mRNA. The two domains are frequently envisioned as being of different age with the CCA domain being older. Support for this idea stems from the fact that the CCA domain alone forms a "minihelix" to which modern tRNA synthetases can readily attach specific amino acids. Such aminoacylation has also been shown with evolved ribozymes (Lee et al. 2000), which can be surprisingly small (Chumachenko et al. 2009). In fact, aminoacylation has been reported without any enzyme or ribozyme at all (Tamura and Schimmel 2004). Furthermore, it has also been reported that a minihelix when incorporated into the 50 S subunit can participate in peptide bond formation (Sardesai et al. 1999). Indeed, even the addition of a single cytosine (equivalent to C75 of modern tRNAs) to puromycin is apparently sufficient to allow peptide bond formation (Brunelle et al. 2006). Thus, it may initially only be necessary to have the CCA segment alone (Nissen et al. 2000). The $5^{\prime}$ domain of the tRNA is not consequential to peptide bond formation and could have been added later. If the tRNAs evolved from the one domain structure or an even simpler structure, then protein synthesis would likely have begun as a noncoded process (Schimmel and Henderson 1994). Single domain or even smaller aminoacylated RNAs are especially attractive in an RNA world where synthesis of larger RNAs is likely to be difficult. Synthesis of random oligomers in the 20-40 size range has been 
G.E. Fox

shown (Joshi et al. 2009; Powner et al. 2009; Szostak, 2009; Ferris et al. 1996) but the path to prebiotic synthesis of large RNAs is not without difficulties (Orgel, 2004).

How does one obtain RNAs of increasing complexity, such as those of modern tRNAs or the PTC RNA, without a true RNA replicase? There are two core possibilities, ligation and hybridization. RNA ligation has been shown to be feasible in an RNA World (Hager et al. 1996; Hager and Szostak 1997; McGinness and Joyce 2002). Thus, it is of interest that the tRNA "cloverleaf" secondary structure can be formed by a direct duplication, e.g., ligation, of an appropriate stem loop structure (Di Guilio 2002). The possible relevance of this idea was enhanced further by the demonstration that it was possible to actually replicate all the major tertiary interactions seen in modern tRNAs when two appropriate stem loop structures were ligated together (Nagaswamy and Fox 2003).

An alternative method of readily obtaining more complex structures is to simply hybridize small fragments to one another such that a larger RNA with many "nicks" is assembled. These nicks might or might not be sealed at a later stage. In Nanoarchaeum equitans, several tRNAs are encoded as partially complementary half molecules, which are then ligated together to form a tRNA (Randau et al. 2005a and b). In Euglena gracillis the large subunit rRNA is comprised of 14 discrete RNA fragments held together by hybridization events that form various helical elements. Not only are the fragments not coded in the order they appear in the final RNA but they are actually intermingled in the genome with similar fragments of the small subunit RNA (Smallman et al. 1996).

\section{Chirality and the Ribosome}

In modern organisms, mechanisms for nonribosomal peptide synthesis exist for specialized purposes and can produce peptides with unusual structures and mixed chirality (Marahiel and Essen 2009). Modern rRNAs and tRNAs are chiral with $\mathrm{D}$ sugars and during translation they work together to make chiral proteins with exclusively L-amino acids. This is highly advantageous to modern organisms because mixed chirality is clearly undesirable for the synthesis of structural elements such as $\alpha$ helices and $\beta$-sheets that characterize modern proteins (Bada 2001; Sandars 2005). It is generally assumed that the modern chiral preferences reflect chiral synthesis of D-ribose in the RNA world (Tamura and Schimmel 2006; Tamura 2008). It thus is likely widely believed that charging of the tRNA by aminoacyl tRNA synthetases and peptide bond formation from their beginnings were chiral. In fact, with atomic resolution structural data now available, a theoretical analysis of the PTC indicates that the natural chirality of the sugar ring in the RNA is well paired with the choice of L-amino acids (Thirumoorthy and Nandi 2008).

Nevertheless, it has been shown that Damino acids can bind to both the $\mathrm{A}$ and $\mathrm{P}$ sites of the ribosome in competition with their Lisomers (Quiggle et al. 1981; Bhuta et al. 1981). When elongation tRNAs carrying D-amino acids are presented to the ribosome in vitro they are incorporated extremely poorly, but incorporated nevertheless (Yamane et al. 1981; Heckler et al. 1988). It has recently been found that peptide synthesis can be effectively initiated with D-amino acids (Goto et al. 2008). In addition, by introducing mutations in the PTC region and/or other nearby regions of the $23 \mathrm{~S}$ rRNA, it was possible to obtain enhanced tolerance of D-amino acids in vitro (Starck et al. 2003; Tan et al. 2004; Dedkova et al. 2003 and 2006). These results suggest that even though the rRNA is itself chiral, the essentially exclusive chirality of the modern ribosome is likely the result of selection rather than being a fundamental property of the PTC.

Regardless, of the preference of the ribosome in the modern machinery, D-amino acids will typically not reach the modern ribosome because the charging reaction also shows a strong but again imperfect chiral preference. For example, tyrosyl-tRNA synthetase is able to transfer both $\mathrm{D}$ and $\mathrm{L}$ tyrosine to its cognate tRNA although the L form is significantly preferred (Sheoran et al. 2009). Consistent with the notion that charging with D-amino acids can occur in vivo, the modern cellular machinery has a variety 
of mechanisms in place to prevent it. These include deacylases that remove D-amino acids from incorrectly charged tRNAs before they reach the ribosome (Soutourina et al. 2000; Yang et al. 2003). In addition, many aminoacyl tRNA synthetases have an editing domain. Nevertheless, the charging reaction has a strong chiral preference even in minihelix reactions (Tamura and Schimmel 2006; Tamura 2008).

Given that the first tRNA charging process was unlikely to better than the modern version, the onset of the ribosome as the machine for making chiral proteins likely emerged not from the chiral exclusivity of its processes, but rather from the fact it is a two tiered process with the same preference at both steps. Thus, if at earlier times $80 \%$ of the tRNAs were charged with an $\mathrm{L}-$ amino acid and $80 \%$ of the tRNAs charged with a D-amino acid were subsequently excluded by the ribosome then $96 \%$ of the residues incorporated into the growing protein would be of the $\mathrm{L}$ type. Thus, a modest peptide of 50 amino acids would perhaps have only two D-amino acids and thus have a good chance of being functional. In fact, incorporation of a D-amino acid into a modern protein is not necessarily destructive to the protein, but instead depends on where it occurs (Dedkova et al. 2003, 2006).

In summary, given that the modern ribosome is not exclusively chiral the early peptide synthesis machinery likely had significantly less chiral specificity. This would be true even if its RNA components were exclusively chiral as the various editing mechanisms associated with the modern charging process would not have been available. Thus, the peptides made by early ribosomes likely included $\mathrm{D}$-amino acids and hence would tend to be unstructured.

Would such peptides be useful? Probably yes. For example, small, largely unstructured peptide segments are found in what are likely the older (not oldest) areas of the modern ribosome. Once the two tier chiral selection procedure used in the modern ribosome was established, refinements in either aspect could quickly improve the likely use of the product peptide. Future studies of partially chiral peptides might provide better insight to the nature of the earliest peptides and clarify the extent of chiral preference in the ribosomal machinery that is needed to begin to produce reasonable numbers of peptides of the modern type.

\section{RNA HISTORY－INFERRING EVENTS BEFORE LUCA}

The PTC and tRNAs clearly existed before LUCA. The fact that we can infer likely if not proven aspects of their history suggests that we can learn about events that occurred before LUCA. But, can we do this in a more general way? A key step is recognition that there are many opportunities to gain insight into relative timing. For example, if a ribosomal protein, ( $\mathrm{r}$-protein), is modified after translation by an enzyme, then there is a timing association between the two proteins. The more difficult second step is to develop evidence pertaining to the relative age of the associated entities, e.g., which is older? In the example, one might initially speculate that the modifying enzyme is newer than its target protein because without a target what good would the modifying enzyme be? However, this might not be the case because the modifying enzyme may have been recruited from somewhere else after the emergence of the r-protein. Finally, the two proteins could have emerged essentially simultaneously.

Given such essentially opposite alternatives, how can they be resolved? The answer will typically be independent information or a likely assumption. If the r-protein is found in all organisms and the modifying enzyme is only in Grampositive bacteria, then it is more likely, but not proven, that the r-protein is older. Not proven because the gene for the modifying protein might have been lost in other lineages. If the protein in question is associated with a duplication event, as is the case with ribosomal proteins L15 and L18e, it may be possible to use phylogenetic arguments to deduce relative age (Roberts et al. 2008). In the example used here, when one examines the structure of the two proteins, the r-protein is much smaller and far simpler, composed only of $\alpha$ helices. Thus, the growing evidence for one hypothesis makes it increasing likely to be correct. Finally, the third step is to find more extensive associations involving multiple timing events. 
G.E. Fox

An examination of the evidence relating to elongation factor $\mathrm{G}$ (EF-G) illustrates how timing information might be combined into a more general hypothesis. It has been argued from atomic resolution structures that EF-G is a structural mimic of elongation factor EFTu when it is part of a ternary complex with GTP and an aminoacylated tRNA (Nissen et al, 1995; Moore, 1996). If true, this hypothesis raises the obvious question of who mimics whom? Because the tRNA is at the core of the translation machinery, it likely arose very early. From this, one can logically argue that EF-G is likely newer. Regardless of the status of molecular mimicry, EF-G is actually not completely essential for the translocation process (Gavrilova \& Spirin, 1971; Gavrilova et al. 1976; Spirin, 2002). Is the timing relationship proven? No, but at this stage it appears more likely than the alternative. Other claims of mimicry in the ribosomal machinery have also been made (Selmer et al. 1999; Nakamura and Ito, 2003).

The nonobvious benefit of the mimicry argument is that one can combine it with the previously discussed argument that tRNAs began as one domain RNAs (Schimmel and Henderson, 1994; Di Guilio, 1994; Schimmel and Ribas de Pouplana 1995). Thus, one produces a combined core time-line for the development of the translation machinery from a one domain tRNA predecessor, to a two domain tRNA, followed by the addition of EF-Tu, and finally the addition of EF-G. However, EF-Tu has been shown in at least one case to bind to a model one domain (minihelix) tRNA (Rudinger et al. 1994) which supports a hypothetical time line that delays the onset of the second tRNA until after the emergence of EF-Tu. This is interesting, because it also delays the possibility of mRNA-tRNA interaction and thus the onset of coding. However, in the absence of coding it is not clear how one produces a sophisticated protein.

\section{DEDUCING THE RELATIVE AGE OF r-PROTEINS}

Given that the ribosome is quite ancient, one might have expected the early r-proteins to have diverged to spawn later ones and possibly even super families of proteins used elsewhere (Ohnishi 1984; Leijonmarck et al. 1987). In fact, there are clear examples of genetic events such as gene fusion, insertion and duplication (Ramakrishnan and White 1998), but in general most r-proteins are structurally distinct. Some likely evolved with the early ribosome and then in some cases were recruited to other functions, whereas others likely evolved elsewhere and got incorporated into the ribosome at later stages. Thus, there are likely to be historical relationships between some of the proteins that will provide timing insights to the development of the subunits. One such example, e.g., S6 and S10, has been uncovered (Jue et al. 1980) and verified by structural data (Brodersen et al. 2002).

Can one deduce the relative age of the various r-proteins? Phylogenetic distribution is an obvious initial indicator with the more widely distributed proteins likely being older. However, many r-proteins are universal in all three Domains of life (Lecompte et al. 2002; Hartman et al. 2006), and hence it is not immediately obvious how one might infer relative age among members of this rather large group. Also, one must be alert to the fact that like the RNAs, all parts of the r-proteins are probably not equally old (Vishwanath et al. 2004). Experimental studies have shown that ribosomal components are assembled in a reproducible manner, which might recapitulate to a significant extent the history of the ribosome and thereby provide timing information. For this reason, it was hypothesized that the oldest proteins would assemble first and be at the core of the process whereas newer proteins would be incorporated into later stages of assembly and the newest proteins would be last (Fox and Naik 2004). The process of in vivo assembly is currently being actively studied at a very detailed level (Klein et al. 2004, Nierhaus 2007). However, traditional maps (Rohland and Nierhaus 1982; Herold and Nierhaus 1987; Nierhaus 1991) that summarize in vitro assembly remain a reasonable approximation of what actually occurs. Consistent with the hypothesis regarding assembly, an initial inspection of the traditional maps shows that the nonuniversal and hence 
likely newer r-proteins are largely incorporated into the ribosome at the final stages of assembly.

To focus on what are likely the oldest proteins, all the nonuniversal proteins and their associated connections were removed from the 50 S subunit assembly map (Fig. 1). The hypothesis here is that the assembly order of the remaining universal r-proteins speaks to their relative age. Thus, although $\mathrm{L} 23$ binds directly to $23 \mathrm{~S}$ rRNA, its assembly is also facilitated by L3 and hence it is likely a newer addition than L3. Another aspect of Figure 1 is that essentially all the remaining r-proteins are still interconnected but some are more connected than others. In complex systems, greater interdependence is likely to be associated with longer association and hence suggests greater age. For example, L1 and L3 are both universal and directly interact with the RNA, however, L3 is more central to the process of assembly and hence likely older.
Genomic organization can also be considered. Universally conserved gene clusters (e.g., operons) are very rare. When genes are associated in conserved operons they are likely to share regulatory relationships. In the case of $\mathrm{r}$ proteins, four clusters of r-proteins (the S10, Str, Spc and L13 operons) are preserved in the Archaea and Bacteria (Siefert et al. 1997). In general, the universal r-proteins are encoded in the universal operons. Thus, r-proteins L2, L3, and L4 are all encoded by the S10 operon. When the assembly information is considered in combination with the other criteria, the results suggest that L2, L3, and L4, are among the oldest r-proteins (Fox and Naik 2004; Tran et al. in preparation). Overall, the conserved large subunit proteins have initially been grouped into four clusters ranging from oldest to most recent. These four groups are (1): L2, L3, L4; (2): L22, L23, L24; (3): L5, L6, L10, L11, L13, L18, L29; and (4): L9, L31, L32-L34.

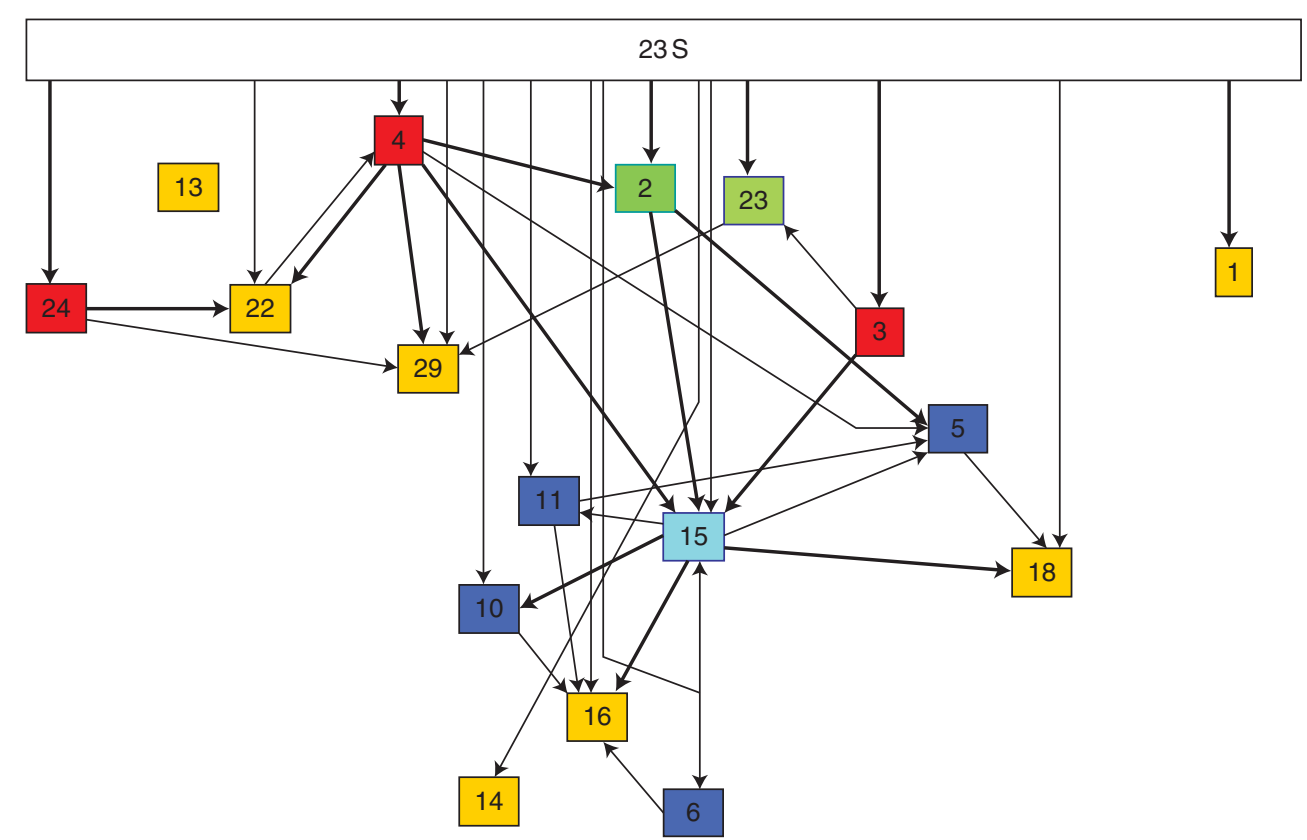

Figure 1. Assembly map of $50 \mathrm{~S}$ ribosomal subunit with all nonuniversal protein omitted. The map was derived from Nierhaus (2001) and is a slightly modified version of that presented previously Fox and Naik (2004). Each protein is indicated by a numbered box with the $23 \mathrm{~S}$ rRNA indicated at the top. Lines with arrows indicate order in assembly with darker lines representing stronger dependencies. Thus L4 and L24 bind directly to the RNA and work together to facilitate the incorporation of L22. Boxes are colored with regard to the similarity of their position in assembly. For example, yellow indicates terminal proteins, which are not required for addition of any other universal protein. 
G.E. Fox

\section{INFERENCES FROM r-PROTEIN STRUCTURE}

Detailed examination of the structure of the older r-proteins and how they interact with the rRNAs is likely to provide insight to the development of the ribosome before LUCA. There are large amounts of information in this regard and to illustrate what might be learned two interesting examples, S1 and L2 will be discussed in some detail. Ribosomal protein L2 is universally distributed, plays a central role in ribosome assembly, is encoded in the universal L10 operon, and is near the PTC although not involved in peptide bond synthesis. Analysis of the assembly map discussed earlier suggests L2 is in fact one of the very oldest proteins. L2 has a RNA binding domain comprised of an OB-fold and an SH3 -like barrel.

The SH3 domain is homologous to similar domains found in the NusG protein (involved in Rho dependent termination of transcription), and two r-proteins, L24 (universal) and L21e (not universal). Although L24 is universal it is actually only required to initiate subunit assembly (Spillmann and Nierhaus 1978), In actuality this role can be assumed by L20 at low temperatures (Franceschi and Nierhaus 1988) and a mutant E. coli strain defective in L24 is viable (Herold et al. 1986). L21e and L24 are thus likely newer than L2 even though L24 binds directly to the rRNA.

The OB-fold is found in r-proteins S1, S12, $\mathrm{S} 17$, and S28e. The OB-fold is a small $\beta$-barrel formed from 5 strands connected by modulating loops; two or three loops on the same face of barrel are consistently observed acting as clamps to bind to their ligands (Agrawal and Kishan 2003). The SH3 domain has a characteristic fold with $\beta$-barrel architecture, which consists of five or six $\beta$-strands arranged as two tightly packed antiparallel $\beta$ sheets. Two prominent loops, termed the RT and n-Src loops, are often seen in the fold (Boggon and Eck 2004). What is especially interesting from the perspective of ribosome origins is that these two folds are actually very similar. In particular, the insertion of strand $\beta 1$ between $\beta 4$ and $\beta 5$ in the SH3-fold would actually create an
OB-fold like topology (Agrawal and Kishan 2001). Thus, not only is L2 a possible progenitor of multiple r-proteins, its modern version may have arisen as a result of a very early (pre LUCA) duplication event creating two copies of one of the folds followed by a rearrangement in one of the domains to create one fold of each type. If this is correct, the obvious next question is which folding domain is older? In fact, the $\mathrm{SH} 3$ domain is encompassed entirely within a universal sequence block (Vishwanath et al. 2004) whereas the OB fold is partially in a block that distinguishes Bacteria and Archaea. This observation suggests that the $\mathrm{SH} 3$ domain may be older although position in the ribosome should also be considered.

Ribosomal protein S1 is substantially larger than all other r-proteins and in contrast with L2 is not integrally part of the ribosome. It is involved in initiation and has been associated with antitermination and trans-translation as well. It lacks an Archaeal homolog and is sometimes missing even in Bacteria suggesting it is post-LUCA addition to the ribosomal machinery. S1 contains six copies of an RNA binding domain (OB fold) that is known as the S1 domain. Many proteins in fact have one or more S1 domains. These include, but are not limited to: Polynucleotide phosphorylase, a bacterial exonuclease that degrades mRNA from $3^{\prime}$ to $5^{\prime}$ (Regnier et al. 1987); the $\alpha$ subunit of the eukaryotic initiation factor 2 (Gribskov, 1992); yeast PRP22, an RNA helicase like protein required for the release of the mRNA from the spliceosome (Company et al. 1991); and the amino-terminal end of ribonuclease $\mathrm{E}$, which is involved in both $5 \mathrm{~S}$ rRNA processing and the rapid degradation of mRNA in E. coli (Kaberdin et al. 1998). Perhaps, the most notable of the proteins that contain S1 domains for the present purposes are the translation initiation factor IF1 and its eukaryotic equivalent eIF1a, both of which also have the characteristic five stranded $\beta$ barrel arrangement (Sette et al. 1997; Battiste et al. 2000). The proteins containing S1 domains can be broadly grouped into three main functional groups of RNA processing, involvement in transcription or translation and chromatin or septum regulation. The S1 
motif is found in all three domains of life with the IF-1/eIF1A type are universally distributed suggesting this might be the original source of the fold. It seems likely that ribosomal protein $\mathrm{S} 1$ is a late addition to the ribosome, possibly derived from the initiation machinery.

\section{EVOLUTION OF THE LARGE RIBOSOMAL RNA}

The substantial structural and sequence conservation seen in comparisons of the rRNAs from all three Domains of life suggest that they reached their modern size early in the development of the ribosome. However, it is not necessarily true and in fact it is extremely unlikely that all parts of the rRNAs are of the same age. Instead, like some of the r-proteins, they have increased in size over time, perhaps beginning as an amalgamation of smaller fragments (Clark 1987; Gray and Schnare 1996). Indeed, the eukaryotic RNAs are tolerant of insertions in certain locations and have clearly grown larger since LUCA (Gray and Schnare 1996; Yokoyama and Suzuki 2008). Thus, cogent arguments have been presented that certain portions of the rRNAs are older than others (Gray and Schnare 1996; Wuyts et al. 2001; Mears et al. 2002; Caetano-Anolles 2002; Hury et al. 2006).

The secondary structure of the large rRNA reveals the presence of six domains in the RNA with the PTC being located in Domain V. Hury et al. (2006) argue that interconnectivity among distant regions can provide insight to historical timing. The argument is that older regions would have more time to be integrated into the structure and hence would show greater connectivity to other regions than newer additions. To implement this timing argument, all of the base-base interactions between regions that were not contiguous in the secondary sequence were counted. A number of regions were identified as being the most connected and hence likely to be the oldest (Fig. 2).

The oldest regions largely overlap with the minimal RNA previously deduced by comparative analysis (Mears et al. 2002) and the observed minimal core (Gutell 1992; Gray and Schnare 1996). In fact, rRNAs comprised of essentially only the regions highlighted in Figure 2 are found in various minimize mitochondrial rRNAs such as the large subunit RNA of Trypanosoma brucei (Sloof et al. 1985). The only exception is the GTPase region (above Region 2.5 on Fig. 2), which is involved in conformational changes during protein synthesis and hence not involved in interactions. It was argued from these results that in addition to Domain V, Domain IV, and a portion of Domain II (2.1 and 2.3 on Fig. 2) were also extremely old but no definitive decision was made regarding relative age. Domain IV is of special interest because it has major contacts with the 30S subunit (Yusupov et al. 2001) The addition of Domain IV to the structure likely corresponds with the beginning of the formation of the $30 \mathrm{~S}$ subunit. Hsiao and Williams (2009) have observed that there are four magnesium microclusters that are shared in ribosome structures by the Bacteria (Thermus thermophilus) and the Archaea (Haloarcula marismortui). These complex clusters occur four times in the large subunit. One cluster is exclusively in the PTC whereas two others connect parts of Domain 2 (Regions 2.1 and 2.3) to Domain 4 and the PTC.

Recently, Bokov and Steinberg (2009) have improved on the connectivity argument by recognizing the potential of using the many Aminor motifs in the large subunit rRNA as timing events. The A-minor motif occurs when a stack of adenosines pack into the minor groove of a duplex region that can be some distance away in the primary sequence of the RNA (Nissen et al. 2001). Such a two-component interaction is inherently a timing event, if one component of the interaction is likely to predate the other. Bokov and Steinberg observed that in most A-minor interactions involving the PTC region (very old) the A stack was in the PTC and the helix was elsewhere (presumably newer). This implied that the A stack usually predated the helix it interacted with. From this assumption, they were able to deduce an order of addition of individual RNA regions as the RNA grew over evolutionary time, and created a hierarchical map of the RNA. The only other region where the A stack portion of the 


\section{G.E. Fox}

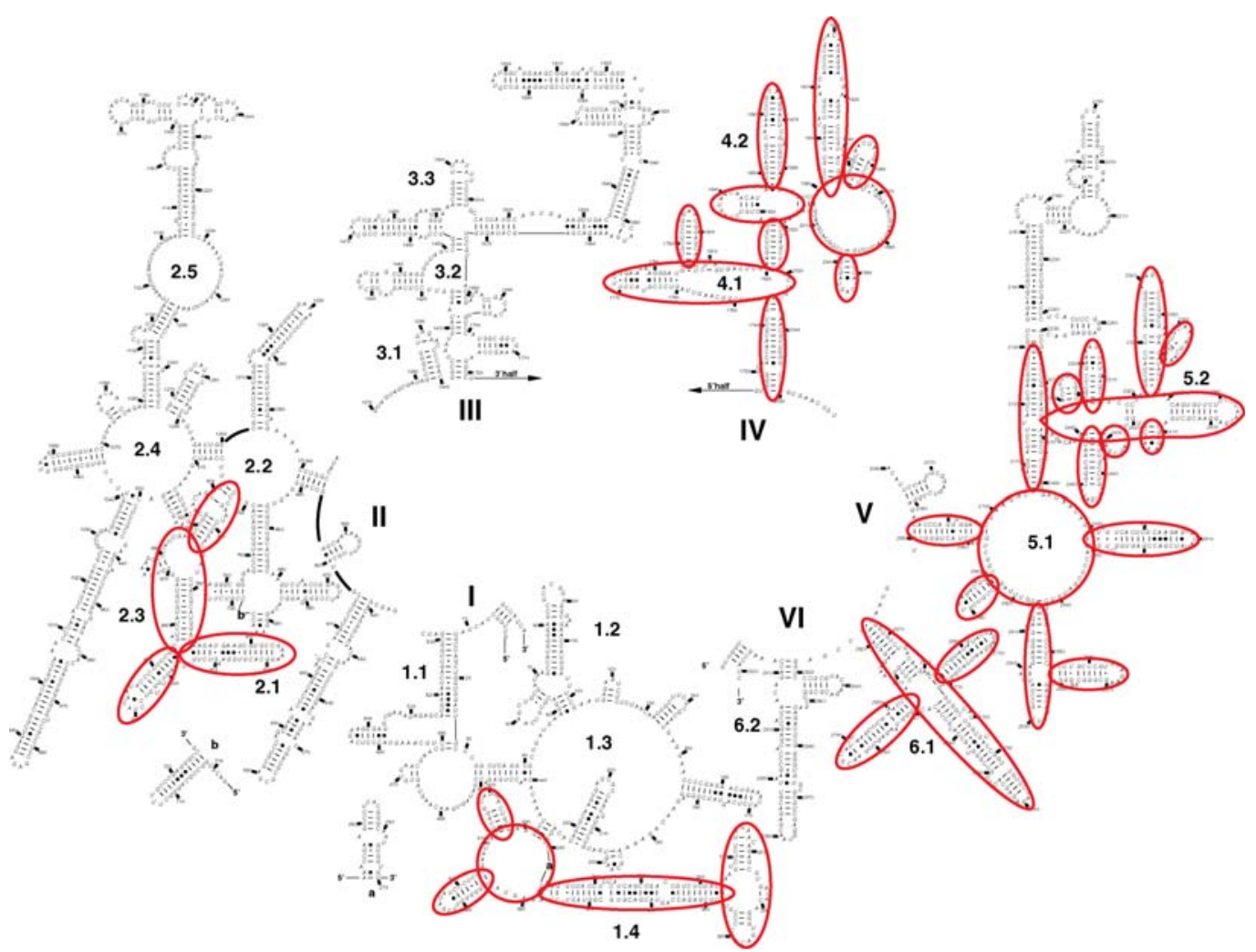

Figure 2. The secondary structure of Haloarcula marismortui $23 \mathrm{~S}$ rRNA is broken into six major domains (I through VI) with subregions in the various domains denoted as 1.1, 1.2, etc. The highlighted regions are the most interconnected as measured by the numbers of base-base interactions between a residue in one domain and a residue in another. The figure is taken from Hury et al. 2006.

interaction is is concentrated is in Domain II (regions 2.1 and 2.3), which suggests that this region is also very old and in fact therefore likely older than Domain IV. Thus, the PTC region is envisioned as beginning its expansion before the small subunit RNA evolved. Because the decoding site is in the small subunit, this suggests that significant enhancement of the machinery occurred well before the beginning of coded peptide synthesis.

The immediate importance of the Bokov and Steinberg (2009) analysis is the ability to derive a hierarchical model of $23 \mathrm{~S}$ rRNA. The core areas of the structure are again the PTC by assumption, the same portions of Domain II (region 2.1 in red on Fig. 2) and parts of Domain 4 as seen by Hury et al. (2006). However, in the context of studies of ribosome evolution, a hierarchical organization is useful in that it offers the potential for organizing diverse data into a single framework. Thus, one may be able to map the emergence of specific regions of various $\mathrm{r}$-proteins to the emergence of particular rRNA segments and using other data possibly time adjust the events on different branches of the rRNA evolution map. Using this perspective, Bokov and Steinberg argue that the acquisition of the GTPase center and L1 protuberance and even the addition of the $30 \mathrm{~S}$ subunit are relatively late additions to the ribosome. These suggestions are largely consistent with the timeline proposed earlier (Fox and Naik 2004).

\section{RECENT RNA AND PROTEIN COEVOLUTION}

An alternative approach to gain insight to how the RNA can change over time is to study changes that have occurred since LUCA. The 
availability of crystal structures of $50 \mathrm{~S}$ ribosomal subunits from both Archaeal and Bacterial species has provided detailed information about the $\mathrm{r}$-proteins that are unique to either the Archaea or Bacteria and how they interact with the RNA (Ban et al. 2000; Yusupov et al. 2001; Schuwirth et al. 2005). Frequently, a protein missing in one system is replaced by a different protein in the other with the implication that these diversifications developed after the divergence of the Bacteria and Achaea (Klein et al. 2004). By examining the relationship between these variable r-proteins and their associated RNA regions in detail, it is possible to document the nature of the coevolution that has occurred between the r-proteins and rRNA since LUCA. One might then, with some risk, infer that similar principles applied in the pre-LUCA era.

A detailed examination revealed that there are few completely unique proteins in either Domain of life. Instead, there are many examples of analogs. These have been analyzed in detail from a structural perspective (Klein et al. 2004). Table 1 summarizes the data for each of the nonuniversal proteins (Wang, 2006). In addition to three Archaeal proteins that have no homolog or analog in the Bacteria, there are three examples in which a single Archaeal protein has a clear analog in the Bacteria and five examples in which the Bacterial analog is comprised of two proteins. In each case, a

Table 1. Nonuniversal r-proteins in Archaea and Bacteria.

\begin{tabular}{|c|c|c|c|}
\hline Arch. & Bact. & Conserved rRNA interaction region & Difference in $23 \mathrm{~S}$ rRNA \\
\hline L18e & $\mathrm{X}$ & $\begin{array}{l}\text { 23S rRNA domain II H28, H30; domain } \\
\text { III H38, H42 }\end{array}$ & Extra H30 in Archaea \\
\hline L19e & $\mathrm{X}$ & $\begin{array}{l}\text { 23S domain I H34; domain II H47, H53, } \\
\text { H57, H58, H60; domain IV H62, H63; } \\
\text { domain VI H96 }\end{array}$ & $\begin{array}{l}\text { H57, H63 are different for Bacteria and } \\
\text { Archaea }\end{array}$ \\
\hline L37ae & $\mathrm{X}$ & $\begin{array}{l}\text { 23S domain II H28, domain III H56, } \\
\text { H58, domain IV H62, H67 }\end{array}$ & H56 is different for Bacteria and Archaea \\
\hline L39e & $\mathrm{X}$ & $\begin{array}{l}23 \mathrm{~S} \text { domain I H6, H10, domain III H49, } \\
\text { H50, H51 }\end{array}$ & No obvious difference \\
\hline $\mathrm{X}$ & $\mathrm{L} 25$ & $5 \mathrm{~S}$ rRNA & No obvious differ \\
\hline $\mathrm{X}$ & L36 & $\begin{array}{l}23 \text { S domain H42, domain V H89, } \\
\text { domainVI H91, H97 }\end{array}$ & No obvious difference \\
\hline L21e & L27 & $\begin{array}{l}\text { 23S domain II H34, domain V H81, } \\
\text { H86; 5S rRNA }\end{array}$ & Slight difference at the end of $\mathrm{H} 86$ \\
\hline $\mathrm{L} 24 \mathrm{e}$ & L19 & 23S domain VI H96, H101 & $\begin{array}{l}\text { No differences for RNA, but different L3 } \\
\text { in Archaea and Bacteria next to L24e } \\
\text { or L19 }\end{array}$ \\
\hline L31e & $\begin{array}{l}\text { L17 } \\
\text { L32 C-end }\end{array}$ & $\begin{array}{l}\text { H47, H61, H96, H100 } \\
\text { H100 }\end{array}$ & $\begin{array}{l}\text { Same secondary and tertiary structures } \\
\text { for both Archaea \& Bacteria }\end{array}$ \\
\hline L37e & L34 & $\begin{array}{l}\text { 23S domain I H5, H8, H23; domain II } \\
\text { H32, H33; domain III H49 }\end{array}$ & $\begin{array}{l}\text { No differences for RNA; has interaction } \\
\text { with proteins. }\end{array}$ \\
\hline \multirow[t]{2}{*}{ L15e } & L9 & $\begin{array}{l}\text { Several residues connecting } 23 \mathrm{~S} \text { domain } \\
\text { IV } \mathrm{H} 75, \mathrm{H} 76\end{array}$ & \multirow{2}{*}{$\begin{array}{l}\text { Extra H15 in some prokaryotic species, } \\
\text { different H10, H79 nearby between } \\
\text { Archaea and Bacteria }\end{array}$} \\
\hline & $\mathrm{L} 31$ & $\begin{array}{l}23 \text { S domain I H11, H13, H15, H21; } \\
\text { domain III H52; domain V H75 }\end{array}$ & \\
\hline \multirow[t]{2}{*}{ L32e } & L20 & $\mathrm{H} 2, \mathrm{H} 25, \mathrm{H} 40, \mathrm{H} 41, \mathrm{H} 45, \mathrm{H} 46$ & \multirow{2}{*}{$\begin{array}{l}\text { Different } \mathrm{H} 25 \text { between Archaea and } \\
\text { Bacteria }\end{array}$} \\
\hline & L21 & $\mathrm{H} 26, \mathrm{H} 40$ & \\
\hline \multirow[t]{2}{*}{ L44e } & L33 & H86, H88 & \multirow{2}{*}{$\begin{array}{l}\text { H68 (only interacts with L44e) and H88 } \\
\text { differ slightly between Arch and Bact. }\end{array}$} \\
\hline & L35 & H13, H86, H88 & \\
\hline
\end{tabular}

The symbol $\mathrm{X}$ indicates no protein is present. Helix numbers are from Yusupov et al. 2001. L7ae is not considered because although it is not universal it is found in some Gram positive bacteria. 
G.E. Fox

rather major change in the protein make up in the ribosome is associated with a very modest change in the RNA.

As an example, the region of the $23 \mathrm{~S}$ rRNA that interacts with L17 and L19 in the E. coli 50S particle interacts instead with L24e and L31e in the H. marismortui 50S subunit. Primary sequence and structural comparisons of these proteins make it clear they are completely unrelated. Thus, the L17/L24e and L19/L24e pairs are clearly analogs created by convergent evolution. In contrast, the RNA structure is largely the same in this region in both the Archaea and Bacteria. Because the RNA structure is largely unchanged, it is likely that the protein components represent independent enhancements (probably mainly stabilization) of an even older RNA. The proteins, however, have likely been added in the Archaeal and Bacterial lineages since the common ancestor. In some cases, the extra protein is found in only one lineage and remains as a "hole" in the other, thus leaving us to speculate whether it has been lost or the use of a having protein at that location has only so far discovered in one lineage. In general, the RNA shows either no structural change or minimal change, whereas the proteins are dramatically different. In essence, we learn nothing about how the RNA grew, but it is very clear that the proteins at least in the post-LUCA era were not the driving force.

\section{TIMELINE OF RIBOSOMAL EVOLUTION}

To better organize the information regarding the origins and subsequent history of the ribosome discussed in the previous sections, it is perhaps useful to attempt to construct a time-line to outline a possible sequence of major events in the context of key historical events (Gray and Schnare 1996; Fox and Naik 2004; Wolf and Koonin 2007). Initial ribosomal development was likely fairly serial, but as its complexity increased it is probable that many developments began to occur in parallel, thus making a linear time line increasingly unrealistic as one approaches the post-LUCA age. In what follows, a scenario that attempts to incorporate the various insights discussed earlier is outlined.
The ribosome as envisioned here would have its earliest beginnings in an RNA world. Amino acids or similar molecules would be attached to very small RNA oligomers. When these RNAs encountered one another in the presence of a RNA ancestral to the PTC RNA, amide bond formation would occur with the result that larger peptide-like molecules would be created. Such a reaction has been shown to be in the realm of possibility in an RNA world (Zhang and Cech 1997). These earliest RNAs would be stabilized by $\mathrm{Mg}^{2+}$. The peptides would be of mixed chirality but enriched for Lamino acids perhaps as a result of an excess of D-ribose in the RNAs of the RNA world. The early peptides might stabilize various RNAs in the RNA world and hence be advantageous. As complexity increased single domain tRNAs and the PTC region would emerge. The PTC region already encompassing the beginnings of the exit tunnel would grow, adding first the core region of Domain II and shortly thereafter portions of Domain IV. At some stage, the decoding domain of the tRNA will be added creating the modern two domain tRNA.

Although there is currently no evidence addressing this, the second domain of the tRNA may have offered the opportunity of anchoring the tRNA to an accessory RNA thereby increasing the amount of time the tRNA is associated with the PTC and hence perhaps increasing the probability of reaction (Wolf and Koonin 2007). The introduction of an anchoring RNA would have been a huge advance. By moving the anchoring RNA, one could move the primitive tRNAs and hence improve their orientations relative the PTC. The growing small ribosomal subunit likely soon took on the task of moving the template leading to the ability to eject used tRNAs and encourage arrival of new ones. Once such an anchoring RNA exists, the unexpected occurs. The anchoring RNA can serve as a template and later as a true mRNA, making it feasible to develop coded synthesis.

Alexander Mankin (see reviewer comments to Wolf and Koonin 2007) and perhaps others have raised the possibility that portions of the small ribosomal subunit RNA originated not in later times as an addition to the growing 
ribosome, but rather separately in the RNA world where it may have originally served as a replicase. Thus, when recruited to the emerging protein synthesis machinery, this RNAwould be capable of traversing a template. Many find this model attractive as it preserves the notion of emergence of an RNA RNA replicase in the RNA world.

The key question regarding the genetic code is not the nature of the assignments, but rather when did a proto mRNA get added to the system? Decoding is inherent to the small subunit as are many of the movements associated with protein synthesis. In particular, the ratcheting motions of the small subunit are largely responsible for the movements of the tRNAs among the A, P, and E sites. Thus, we need to know the order of development of various regions in the small subunit and how their emergence tracks the development of the large subunit. At present this information is not readily available.

Once a true mRNA and core small subunit movements are in place, the ribosome would become increasingly complex by adding early conserved proteins such as L2, L3 and L4. Further expansion of the rRNA could occur by subsequent additions, for example the 5S rRNA and its associated proteins. With the onset of coding, it would be useful to store information, so an early RNA genome perhaps consisting of multiple $10 \mathrm{~KB}$ or less RNA fragments would likely exist. What would that first genome encode? Clearly, one possibility is the conserved r-protein clusters, all of which are regulated at the RNA level (Siefert et al. 1997; Olsen and Woese 1997).

The next major step would be the addition of the modern versions of the GTPase center to the large ribosomal subunit with a resulting major increase in synthesis rates. This would allow a great radiation of cell types and likely end the age of progenotes (Woese and Fox 1977) while bringing on the post-LUCA age. Consistent with this late addition of the GTPase center is the recent argument (Frank and Gonzalez 2010) that the ribosome is essentially a Brownian motor and that EF-G is ancillary rather than instrumental in promoting movements.
Further refinements would be ongoing at this stage such as improvements in initiation, the addition of the exit site, the addition of L1, which facilitates entrance of tRNAs, introduction of posttranscriptionally modified nucleotides, and the enzymes that create them etc. The Archaeal and Bacterial RNAs would be largely fixed but newer nonuniversal proteins would be added and integration between protein synthesis and transcription increased. Ultimately limitations on genome size and stability would lead to early RNA genomes being replaced by DNA genomes.

\section{CHALLENGES AND FUTURE DIRECTIONS}

It is clear from what is presented here that much can already be inferred about the history of the ribosome in times that preceded LUCA. In the earliest stages of ribosome evolution, the cellular entities carrying "protoribosomes" would have lacked a genetic code and the complex dynamic systems of the modern ribosome. Such an entity would thus be in the "throes of evolving the genotype-phenotype relationship" and would be properly considered to be a progenote (Woese and Fox 1977). By the time of LUCA, the ribosome clearly exists in essentially its modern form. This strongly suggests that the ribosome reached a critical stage of development that facilitated the final transition from the RNA world to the RNA / protein world. What was the causative event in ribosome history? It might be argued that it was coding, but if this were the case the LUCA ribosome would likely be much more primitive. It should instead be a development that is taking place as the LUCA ribosome emerges. It is argued here and elsewhere (Hury et al. 2006; Grela et al. 2008) that this key event was the addition of the GTPase center to the ribosome. Although not essential to synthesis, the GTPase center dramatically increases the rate of peptide synthesis (Gavrilova and Spirin 1971; Gavrilova et al. 1976; Spirin 2002). Such an increase may have facilitated the transition from an RNA world to a RNA/protein world.

Looking toward future studies, the evolution of the small ribosomal subunit and its 


\section{G.E. Fox}

RNA are starkly missing from what is presented here. There is an assembly map of the 30 S subunit (Nomura et al. 1984) and efforts to refine it are being actively pursued (Sykes and Williamson 2009 and others). It is clear that the head region, which includes the decoding site is actively involved in the ratcheting motions (Frank and Agrawal 2000) and hence the universal proteins in the $3^{\prime}$ domain of the $16 \mathrm{~S}$ rRNA such as S7 are likely among the oldest. Clearly a major next step will be to examine the small subunit in detail with particular emphasis on the dynamic motions that occur during translation. A key to understanding small subunit history will be detailed knowledge of how and especially where these structural rearrangements occur. Such knowledge is just now reaching the literature (Bashan and Yonath 2008; Munro et al. 2009; Zhang et al. 2009) and has not yet been digested by the origins community. The small subunit is not the only missing piece. There are other aspects of the story that have not been addressed here. These include the evolutionary development of the aminoacyl tRNA synthetases, the initiation and termination aspects of translation, and the maturation and modification process that the RNAs and to a lesser extent the proteins undergo.

There are already substantial amounts of information in the literature regarding these and other issues which need to be brought together in the near future, perhaps as a community Wiki site on ribosome evolution similar to what is being performed for RNA families (Daub et al. 2008). This is especially true for aspects of translation that evolved entirely or in part after LUCA. For example, initiation differs significantly between Bacteria and the Archaea/Eucaryota, but nevertheless several key components are shared (Hernandez, 2008). Thus, IF-1 and eIF-2 in share an RNAbinding motif with r-protein S1 (Gribskov 1992). An examination of the Archaeal unique r-proteins (Wang et al. 2009) showed that many are genomically clustered with genes involved in transcription and initiation. In contrast, the older universal r-proteins are exclusively associated with one another with the single exception of integration with the core subunits of the RNA polymerase. Thus, there is some possibility that studies of ribosome origins may eventually expand to include other cellular processes.

In the end, no matter how complete a picture is developed of ribosomal development over time it will be hypothetical. The ultimate issue will be to prove at least the major parts of it. Thus, laboratory reconstructions will be needed. However, there would be limited value in resurrecting the complete ribosome of LUCA, because it was in effect a modern ribosome itself. An easier and likely equally informative task would be to obtain high resolution structural information on the minimalized ribosomes found in various mitochondria. Laboratory reconstructions may instead best focus on examining meaningful pieces.

For example, in the case of both major tRNA synthetase families, it is the catalytic subunit that is by far the most conserved (O'Donoghue et al. 2003). Other less conserved subunits provide the ability to recognize specific tRNAs and to edit charging errors. One can therefore infer a timeline for increased complexity of these multisubunit enzymes in which the ability to aminoacylate precedes these other features. That is to say, the ability to aminoacylate small RNAs may predate the ability to distinguish individual RNAs as being appropriate targets for the addition of particular amino acids. Thus, the first synthetases may have aminoacylated largely randomly. A relevant experiment then would be to reconstruct an ancestral synthetase catalytic subunit and see if it can charge a one domain tRNA and if so, with what amino acids. However, the critical first target for reconstruction will be the PTC and efforts in this direction have already begun (Davidovich et al. 2009). A full fledged experimental program will become possible if it can be shown that a PTC fragment can catalyze peptide bond formation when presented with CCA terminated RNAs carrying amino acids.

\section{REFERENCES}

Agmon I, Bashan A, Zarivach R, Yonath A. 2005. Symmetry at the active site of the ribosome: Structural and functional implications. Biol Chem 386: 833-844. 
Agrawal V, Kishan RK. 2001. Functional evolution of two subtly different (similar) folds. BMC Struct Biol 1: 5.

Agrawal V, Kishan KV. 2003. OB-fold: Growing bigger with functional consistency. Curr Protein Pept Sci 4: 195-206.

Anantharaman V, Koonin EV, Aravind L. 2002. Comparative genomics and evolution of proteins involved in RNA metabolism. Nucleic Acids Res 30: 1427-1464.

Bada JL. 2001. State-of-the-art instruments for detecting extraterrestrial life. Proc Natl Acad Sci 98: 797-800.

Bailey S, Wing RA, Steitz TA. 2006. The structure of T. aquaticus DNA polymerase III is distinct from eukaryotic replicative DNA polymerases. Cell 126: 893-904.

Ban N, Nissen P, Hansen J, Moore PB, Steitz TA. 2000. The complete atomic structure of the large ribosomal subunit at 2.4 A resolution. Science 289: 905-920.

Bashan A, Yonath A. 2008. Correlating ribosome function with high resolution structures. Trends Microbiol 16: 326-335.

Battiste JL, Pestova TV, Hellen CU, Wagner G. 2000. The eIF1A solution structure reveals a large RNA-binding surface important for scanning function. Mol Cell 5: 109-119.

Benner SA, Cohen MA, Gonnet GH, Berkowitz DB, Johnsson KP. 1993. Reading the palimpset: Contemporary biochemical data and the RNA world. In Gasteland R.F. Atkins J.F. eds. The RNA world. 1st ed. Cold Spring Harbor: Cold Spring Harbor Laboratory Press, pp 27-70.

Bhuta A, Quiggle K, Ott T, Ringer D, Chladek S. 1981. Stereochemical control of ribosomal peptidyltransferase reaction. Role of amino acid side chain orientation of acceptor substrate. Biochemistry 20: 8-15.

Boggon TJ, Eck MJ. 2004. Structure and regulation of Src family kinases. Oncogene 23: 7918-7927.

Bokov K, Steinberg SV. 2009. A hierarchical model for evolution of 23S ribosomal RNA. Nature 457: 977-980.

Brimacombe R. 1991. RNA-protein interactions in the Escherichia coli ribosome. Biochimie 73: 927-936.

Brodersen DE, Clemons WM Jr, Carter AP, Wimberly BT, Ramakrishnan V. 2002. Crystal structure of the 30 S ribosomal subunit from Thermus thermophilus: Structure of the proteins and their interactions with $16 \mathrm{~S}$ RNA. J Mol Biol 316: 725-768.

Brunelle JL, Youngman EM, Sharma D, Green R. 2006 The interaction between C75 of tRNA and the A loop of the ribosome stimulates peptidyl transferase activity. RNA 12: 33-39.

Caetano-Anolles G. 2002. Tracing the evolution of RNA structure in ribosomes. Nucleic Acids Res 30: 2575-2587.

Calendar R, Berg P. 1967. D-Tyrosyl RNA: Formation, hydrolysis and utilization for protein synthesis. $J \mathrm{Mol}$ Biol 26: 39-54.

Chumachenko NV, Novikov Y, Yarus M. 2009. Rapid and simple ribozymic aminoacylation using three conserved nucleotides. J Am Chem Soc 131: 5257-5263.

Clark CG. 1987. On the evolution of ribosomal RNA. J Mol Evol 25: 343-350.

Company M, Arenas J, Abelson J. 1991. Requirement of the RNA helicase-like protein PRP22 for release of messenger RNA from spliceosomes. Nature 349: 487-493.
Connell SR, Takemoto C, Wilson DN, Wang H, Murayama K, Terada T, Shirouzu M, Rost M, Schüler M, Giesebrecht J, et al. 2007. Structural basis for interaction of the ribosome with the switch regions of GTP-bound elongation factors. Mol Cell 25: 751-764.

Danchin A, Fang G, Noria S. 2007. The extant core bacterial proteome is an archive of the origin of life. Proteomics 7: 875-889.

Daub J, Gardner PP, Tate J, Ramskold D, Manske M, Scott WG, Weinberg Z, Griffiths-Jones S, Bateman A. 2008. The RNA WikiProject: Community annotation of RNA families. RNA 14: 2462-2464.

Davidovich C, Belousoff M, Bashan A, Yonath A. 2009. The evolving ribosome: From non-coded peptide bond formation to sophisticated translation machinery. Res Microbiol. Jul 18 [Epub ahead of print]

Dedkova LM, Fahmi NE, Golovine SY, Hecht SM. 2003. Enhanced D-amino acid incorporation into proteins by modified ribosomes. J Am Chem Soc 125: 6616-6617.

Dedkova LM, Fahmi NE, Golovine SY, Hecht SM. 2006. Construction of modified ribosomes for incorporation of D-amino acids into proteins. Biochemistry 45: 15541-15551.

Di Giulio M. 1992. On the origin of the transfer RNA molecule. J Theor Biol 159: 199-214.

Di Giulio M. 1994. On the origin of protein synthesis: A speculative model based on hairpin RNA structures. J Theor Biol 171: 303-308.

Di Giulio M. 2009. A comparison among the models proposed to explain the origin of the tRNA molecule: A synthesis. J Mol Evol 69: 1-9.

Ferris JP, Hill AR Jr, Liu R, Orel LE. 1996. Synthesis of long prebiotic oligomers on mineral surfaces. Nature 381: $59-61$.

Fox GE, Naik AK. 2004. The evolutionary history of the ribosome, In The genetic code and the origin of life (Ribas de Pouplana L. ed), Landes Bioscience Chapter 6, pp 92-105.

Franceschi FJ, Nierhaus KH. 1988. Ribosomal protein L20 can replace the assembly-initiator protein L24 at low temperatures. Biochemistry 27: 7056-7059.

Frank J, Agrawal RK. 2000. A ratchet-like inter-subunit reorganization of the ribosome during translocation. Nature 406: 318-322.

Frank J, Gonzalez RL Jr. 2010. Structure and dynamics of a processive Brownian motor: The translating ribosome. Annu Rev Biochem 2010 Mar 17 [Epub ahead of print].

Gavrilova LP, Spirin AS. 1971. Stimulation of "nonenzymic" translocation in ribosomes by p-chloromercuribenzoate. FEBS Lett 17: 324-326.

Gavrilova LP, Kostiashkina OE, Koteliansky VE, Rutkevich NM, Spirin AS. 1976. Factor-free ("Non-enzymic") and factor-dependent systems of translation of polyuridylic acid by Escherichia coli ribosomes. J Mol Bio 101: 537-552.

Goto Y, Murakami H, Suga H. 2008. Initiating translation wih D-amino acids. RNA 14: 1390-1398.

Gray MW, Schnare MN. 1996. Evolution of rRNA gene organization, in Ribosomal RNA Structure, Evolution, Processing, and Function in Protein Biosynthesis (eds 


\section{G.E. Fox}

R.A. Zimmerman, and A.E. Dahlberg), CRC Press, Boca Raton FL. pp49-69.

Grela P, Bernado P, Svergun D, Kwiatowski J, Abramczyk D, Grankowski N, Tchorzewski M. 2008. Structural relationships among the ribosomal stalk proteins from the three Domains of life. J Mol Evol 67: 154-167.

Gribskov M. 1992. Translational initiation factors IF-1 and eIF-2 $\alpha$ share an RNA-binding motif with prokaryotic ribosomal protein $\mathrm{S} 1$ and polynucleotide phosphorylase. Gene 119: 107-111.

Gutell RR. 1992. Evolutionary characteristics of $16 \mathrm{~S}$ and 23S rRNA structures, in The Origin and Evolution of the Cell (eds H. Hartman and K. Matsuno), World Scientific, pp. 243-309.

Hager AJ, Szostak JW. 1997. Isolation of novel ribozymes that ligate AMP-activated RNA substrates. Chem Biol 4: 607-617.

Hager AJ, Pollard JD, Szostak JW. 1996. Ribozymes: aiming at RNA replication and protein synthesis. Chem Biol 3: 717-725.

Heckler TG, Roesser JR, Xu C, Chang PI, Hecht SM. 1988. Ribosomal binding and dipeptide formation by misacylated tRNA ${ }^{\text {Phe's }}$. Biochemistry 27: 7254-7262.

Hernandez G. 2008. Was the initiation of translation in early eukaryotes IRES-driven? Trends Biochem Sci 33: 58-64.

Herold M, Nierhaus KH. 1987. Incorporation of six additional proteins to complete the assembly map of the 50 $\mathrm{S}$ subunit from Escherichia coli ribosomes. J Biol Chem 262: $8826-8833$

Herold M, Nowotny V, Dabbs ER, Nierhaus KH. 1986. Assembly analysis of ribosomes from a mutant lacking the assembly-initiator protein L24: lack of L24 induces temperature sensitivity. Mol Gen Genetics 203: 281-287.

Hsiao C, Williams LD. 2009. A recurrent magnesiumbinding motif provides a framework for the ribosomal peptidyl transferase center. Nucl Acids Res 37: 31343142.

Hsiao C, Mohan S, Kalahar BK, Williams LD. 2009. Peeling the onion: Ribosomes are ancient molecular fossils. Mol Biol Evol 26: 2415-2425.

Hury J, Nagaswamy U, Larios-Sanz M, Fox GE. 2006. Ribosome origins: The relative age of $23 \mathrm{~S}$ rRNA domains. Orig Life Evol Biosphere 36: 421-429.

Joshi PC, Aldersley MF, Delano JW, Ferris JP. 2009. Mechanism of montmorillonite catalysis in the formation of RNA oligomers. J Am Chem Soc 131: 13369-13374.

Jue RA, Woodbury NW, Doolittle RF. 1980. Sequence homologies among E. coli ribosomal proteins: Evidence for evolutionarily related groupings and internal duplications. J Mol Evol 15: 129-148.

Kaberdin VR, Miczak A, Jakobsen JS, Lin-Chao S, McDowall KJ, von Gabain A. 1998. The endoribonucleolytic Nterminal half of Escherichia coli RNase E is evolutionarily conserved in Synechocystis sp. and other bacteria but not the C-terminal half, which is sufficient for degradosome assembly. Proc Natl Acad Sci 95: 11637-11642.

Klein DJ, Moore PB, Steitz TA. 2004. The roles of ribosomal proteins in the structure assembly, and evolution of the large ribosomal subunit. J Mol Biol 340: 141-177.
Kyrpides N, Overbeek R, Ouzounis C. 1999. Universal protein families and the functional content of the last universal common ancestor. J Mol Evol 49: 413-423.

Lazcano A. 1994. Cellular evolution during the early Archaea: What happened between the progenote and the cenancestor? Microbiologia SEM 11: 13-18.

Lecompte O, Ripp R, Thierry JC, Moras D, Poch O. 2002. Comparative analysis of ribosomal proteins in complete genomes: An example of reductive evolution at the domain scale, Nucleic Acids Res 30: 5382-5390.

Lee N, Bessho Y, Wei K, Szostak JW, Suga H. 2000. Riboszyme-catalyzed tRNA aminoacylation. Nat Struct Biol 7: 28-33.

Leijonmarck M, Liljas A. 1987. Structure of the C-terminal domain of the ribosomal protein L7/L12 from Eschericia coli at 1.7A. J Mol Biol 195: 555-579.

McGinness KE, Joyce GF. 2002. RNA-catalyzed RNA ligation on an external RNA template. Chem Biol 9: 585-596.

Maizels N, Weiner AM. 1993. The genomic tag hypothesis: modern viruses as molecular fossils of ancient strategies for genomic replication. In: Gesteland R.F., Atkins J.F. (eds) The RNA World, Cold Springs Harbor Laboratory Press, Plainview, NY, pp 577-602.

Maizels N, Weiner AM. 1994. Phylogeny from function: evidence from the molecular fossil record that tRNA originated in replication, not translation. Proc Natl Acad Sci 91: 6729-6734.

Marahiel MA, Essen O. 2009. Chapter 13. Nonribosomal peptide synthetases mechanistic and structural aspects of essential domains. Methds Enzymol 458: 337-351.

Mears JA, Cannone JJ, Stagg SM, Gutell RR, Agrawal RK, Harvey SC. 2002. Modeling a minimal ribosome based on comparative sequence analysis. J Mol Biol 321: 215-234.

Moore PB. 1996. Molecular mimicry in protein synthesis. Science 270: 1453-1454.

Munro JB, Sanbonmatsu KY, Spahn CM, Blanchard SC. 2009. Navigating the ribosome's metastable energy landscape. Trends Biochem Sci 34: 390-400.

Mushegian AR, Koonin EV. 1996. A minimal gene set for cellular life derived by comparison of complete bacterial genomes. Proc Natl Acad Sci 93: 10268-10273.

Nagaswamy U, Fox GE. 2003. RNA ligation and the origin of tRNA. Orig Life Evol Biosph 36: 421-429.

Nakamura Y, Ito K. 2003. Making sense of mimic in translation termination. Trends in Biochem Sci 28: 99-105.

Nierhaus KH. 1991. The assembly of prokaryotic ribosomes. Biochimie 73: 739-755.

Nierhaus KH. 2007. Question 6: Early steps of evolution and some ideas about a simplified translational machinery. Orig Life Evol Biosph 37: 391-398.

Nissen P, Hansen J, Ban H, Moore PB, Steitz TA. 2000. The structural basis of ribosome activity in peptide bond synthesis. Science 289: 920-930.

Nissen P, Ippolito JA, Ban N, Moore PB, Steitz TA. 2001. RNA tertiary interactions in the large ribosomal subunit: The A-minor motif. Proc Natl Acad Sci 98: 4899-4903.

Nissen P, Kjeldgaard M, Thirup S, Polekhina G, Reshetnikova L, Clark BF, Nyborg J. 1995. Crystal structure of 
the ternary complex of PhetRNA ${ }^{\text {Phe }}$ EFTu and a GTP analog. Science 270: 1464-1472.

Noller HF. 1993. On the origin of the ribosome: Co-evolution of sub-domains of tRNA and rRNA, In: Gesteland R.F., Atkins J.F. (eds) The RNA world, Cold Springs Harbor Laboratory Press, Plainview, NY, pp 137-156.

Nomura M, Gourse R, Baughman G. 1984. Regulation of the synthesis of ribosomes andribosomal components. Annu Rev Biochem 53: 75-117.

O’Donoghue P, Luthey-Schulten Z. 2003. On the evolution of structure in aminoacyl-tRNA synthetases. Microbiol Mol Biol Rev 67: 550-573.

Ohnishi K. 1984. Towards a classification of E. coli ribosomal proteins: a hypothetical 'small ribosome' as a primitive protein-synthesizing apparatus. Orig Life 14: 717-724.

Olsen GJ, Woese CR. 1997. Archaeal genomics: an overview. Cell 89: 991-994.

Orgel LE. 2004. Prebiotic chemistry and the origin of the RNA world. Crit Rev Biochem Mol Biol 39: 99-123.

Powner MW, Gerland B, Sutherland JD. 2009. Synthesis of activated pyrimidines ribonucleotides in prebiotically plausible conditions. Nature 459: 239-242.

Quiggle K, Kumar G, Ott TW, Ryu EK, Chladek S. 1981. Donor site of ribosomal peptidyltransferase: Investigationof substrate specificity using $2^{\prime}\left(3^{\prime}\right)-\mathrm{O}-(\mathrm{N}$-acyaminoacyl)dinucleoside phosphates as models of the $3^{\prime}$ terminus of $\mathrm{N}$-acylaminoacyl transfer ribonucleic acid. Biochemistry 20: 3480-3485.

Ramakrishnan V, White SW. 1998. Ribosomal protein structures: insights into the architecture, machinery and evolution of the ribosome. Trends Biochem Sci 23: 208-212.

Randau L, Calvin K, Hall M, Yuan J, Podar M, Li H, Söll D. 2005a. The heteromeric Nanoarchaeum equitans splicing endonuclease cleaves noncanonical bulge-helix-bulge motifs of joined tRNA halves. Proc Natl Acad Sci 102: 17934-17939.

Randau L, Münch R, Hohn MJ, Jahn D, Söll D. 2005b. Nanoarchaeum equitans creates functional tRNAs from separate genes for their $5^{\prime}$ - and $3^{\prime}$-halves. Nature 433: 537-541.

Regnier P, Grunberg-Manago M, Portier C. 1987. Nucleotide sequence of the pnp gene of Escherichia coli encoding polynucleotide phosphorylase. Homology of the primary structure of the protein with the RNA-binding domain of ribosomal protein S1. J Biol Chem 262: 63-68.

Roberts E, Montoya J, Sethi A, Woese CR, Luthey-Schulten Z. 2008. Molecular signatures of the past. Proc Natl Acad Sci USA 105: 13953-13958.

Rohland R, Nierhaus KH. 1982. Assembly map of the large subunit (50S) of Escherichia coli ribosomes. Proc Natl Acad Sci 79: 729-733.

Rudinger J, Blechschmitd B, Ribeiro S, Sprinzl M. 1994. Minimalist aminoacylated RNAs as efficient substrates for elongation factor Tu. Biochemistry 33: 5682-5688.

Sandars PGH. 2005. Chirality in the RNAworld and beyond. Intn J Astrobiol 4: 49-61.

Sardesai NY, Green R, Schimmel P. 1999. Efficient 50S ribosome-catalyzed peptide bond synthesis with an aminoacyl minihelix. Biochemistry 38: 12080-12088.
Schimmel P, Giege R, Moras D, Yokoyama S. 1993. An operational RNA code foramino acids and possible relationship to genetic code. Proc Natl Acad Sci USA 90: 87638768.

Schimmel P, Henderson B. 1994. Possible role of aminoacylRNA complexes in noncoded peptide synthesis and origin of coded synthesis. Proc Natl Acad Sci 91: 11283-11286.

Schimmel P, Ribas de Pouplana L. 1995. Transfer RNA: From minihelix to genetic code. Cell 81: 983-986.

Schuwirth BS, Borovinskaya MA, Hau CW, Zhang W, Vila-Sanjurjo A, Holton JM, Cate JH. 2005. Structure of the bacterial ribosome at $3.5 \mathrm{~A}$ resolution. Science 310: $827-834$.

Selmer M, Al-Karadaghi S, Hirokawa G, Kaji A, Liljas A. 1999. Crystal structure of Thermotoga maritima ribosome recycling factor: a tRNA mimic. Science 286: 2349-2352.

Selmer M, Dunham CM, Murphy FV 4th, Weixlbaumer A, Petry S, Kelley AC, Weir JR, Ramakrishnan V. 2006. Structure of the 70S ribosome complexed with mRNA and tRNA. Science 313: 1935-1942.

Sette M, van Tilborg P, Spurio R, Kaptein R, Paci M, Gualerzi CO, Boelens R. 1997. The structure of the translational initiation factor IF1 from $E$. coli contains an oligomer -binding motif. EMBO J 16: 1436-1443.

Sheoran A, Sharma G, First EA. 2008. Activation of Dtyrosine by Bacillus stearothermophilus tyrosyl-tRNA synthetase: 1. Pre-steady-state kinetic analysis reveals the mechanistic basis for the recognition of D-tyrosine. $J$ Biol Chem 283: 12971-12980.

Siefert JL, Martin KA, Abdi F, Widger WR, Fox GE. 1997. Conserved gene clusters in bacterial genomes provide further support for the primacy of RNA. J Mol Evol 45: $467-472$.

Simonović M, Steitz TA. 2008. Cross-crystal averaging reveals that the structure of the peptidyl-transferase center is the same in the 70S ribosome and the 50S subunit Proc Natl Acad Sci USA 105: 500-505.

Sloof P, Van den Burg J, Voogd A, Benne R, Agostinelli M, Borst P, Gutell R, Noller H. 1985. Further characterization of the extremely small mitochondrial ribosomal RNAs from trypanosomes: a detailed comparison of the $9 \mathrm{~S}$ and $12 S$ RNAs from Crithidia fasciculate and Trypanosoma brucei with rRNAs from other organisms. Nucleic Acids Res 13: 4171-4190.

Smallman DS, Schnare MN, Gray MW. 1996. RNA:RNA interactions in the large subunit ribosomal RNA of Euglena gracilis. Biochim Biophys Acta 1305: 1-6.

Smith TF, Lee JC, Gutell RR, Hartman H. 2008. The origin and evolution of the ribosome. Biol Direct 3: 16.

Soutourina J, Plateau P, Blanquet S. Metabolism of D-aminoacyl-tRNAs in Escherichia coli and Saccharomyces cerevisiae cells. J Biol Chem 275: 32535-32542.

Spillmann S, Nierhaus KH. 1978. The ribosomal protein L24 of Escherichia coli is an assembly protein. J Biol Chem 253: 7047-7050.

Spirin AS. 2002. Ribosome as a molecular machine. FEBS Lett 514: 2-10.

Starck SR, Qi X, Olsen BN, Roberts RW. 2003. The puromycin route to assess stero- and regiochemical constraints 


\section{G.E. Fox}

on peptide bond formation in eukaryotic ribosomes. J Am Chem Soc 125: 8090-8091.

Steitz TA. 2008. A structural understanding of the ribosome. Nat Rev Mol Cell Biol 9: 242-253.

Sykes MT, Williamson JR. 2009. A complex assembly landscape for the $30 \mathrm{~S}$ ribosomal subunit. Annu Rev Biophys 38: $197-215$.

Szostak JW. 2009. Systems chemistry on early earth. Nature 459: $171-172$.

Tamura K. 2008. Origin of amino acid homochirality: relationship with the RNA world and origin of tRNA aminoacylation. Biosystems 92: 91-98.

Tamura K, Schimmel P. 2004. Non-enzymatic aminoacylation of an RNA minihelix with an aminoacyl phosphate oligonucleotide. Nucleic Acids Symp Ser 48: 269-270.

Tamura K, Schimmel PR. 2006. Chiral-selective aminoacylation of an RNA minihelix: mechanistic features and chiral suppression. Proc Natl Acad Sci 103: 13750-13752.

Tan Z, Forster AC, Blacklow SC, Cornish VW. 2004. Amino acid backbone specificity of the Escherichia coli translation machinery. J Am Chem Soc 126: 12752-12753.

Thirumoorthy K, Nandi N. 2008. Role of chirality of the sugar ring in the ribosomal peptide synthesis. J Phys Chem B 112: 9187-9195.

Vishwanath P, Favaretto P, Hartman H, Mohr SC, Smith TF 2004. Ribosomal protein-sequence block structure suggests complex prokaryotic evolution with implications for the origin of eukaryotes. Mol Phylo Genet Evol 33: 615-625.

Wang J. 2006. From genome to structure: comparative studies of archaeal unique ribosomal proteins. Ph. D. Dissertation, University of Houston, Houston, TX.

Wang J, Dasgupta I, Fox GE. 2009. Many non-universal archaeal ribosomal proteins are found in conserved gene clusters. Archaea 2: 241-251.
Wimberly BT, Brodersen DE, Clemons WM Jr, MorganWarren RJ, Carter AP, Vonrhein C, Hartsch T, Ramakrishnan V. 2000. Structure of the 30 S ribosomal subunit. Nature 407: 327-339.

Woese CR, Fox GE. 1977. The concept of cellular evolution. J Mol Evol 10: 1-6.

Wolf YI, Koonin EV. 2007. On the origin of the translation system and the genetic code in the RNA world by means of natural selection, exaptation, and subfunctionalization. Biology Direct 2: 14.

Wuyts J, Van de Peer Y, De Wachter R. 2001. Distribution of substitution rates and locations of insertion sites in the tertiary structure of ribosomal RNA. Nucleic Acids Res 29: 5017-5028.

Yamane T, Miller DL, Hopfield JJ. 1981. Discrimination between D and L-tyrosyl transfer ribonucleic acids in peptide chain elongation. Biochemistry 20: 7059-7068.

Yang H, Zheng G, Peng X, Qiang B, Yuan J. 2003. D-Amino acids and D-Tyr-tRNA ${ }^{\text {tyr }}$ deacylase: Stereospecificity of the translation machine revisited. FEBS Lett 552: 95-98.

Yokoyama T, Suzuki T. 2008. Ribosomal RNAs are tolerant towards genetic insertions: Evolutionary origin of expansion segments. Nucleic Acids Res 36: 3539-3551.

Yusupov MM, Yusupova GZ, Baucom A, Lieberman K, Earnest TN, Cate JH, Noller HF. 2001. Crystal structure of the ribosome at 5.5 A resolution. Science 292: 883-896.

Zhang B, Cech TR. 1997. Peptide bond formation by in vitro selected ribozymes. Nature 390: 96-100.

Zhang W, Dunkle JA, Cate JHD. 2009. Structures of the ribosome in intermediate states of ratcheting. Science 325: 12014-1017.

Zimmerman E, Yonath A. 2009. Biological implications of the ribosomes's stunning stereochemistry. Chembiochem 10: $63-72$. 


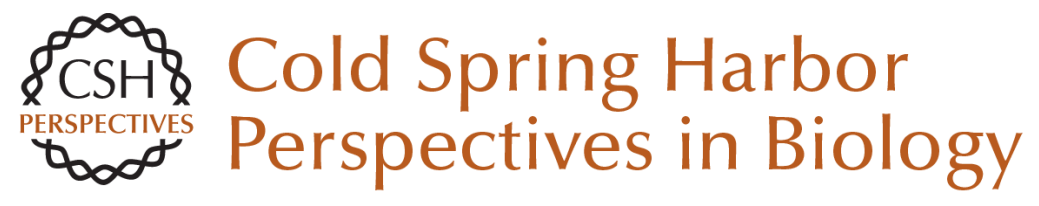

\section{Origin and Evolution of the Ribosome}

George E. Fox

Cold Spring Harb Perspect Biol 2010; doi: 10.1101/cshperspect.a003483 originally published online June 9, 2010

\section{Subject Collection The Origins of Life}

Constructing Partial Models of Cells Norikazu Ichihashi, Tomoaki Matsuura, Hiroshi Kita, et al.

Ribonucleotides John D. Sutherland

Deep Phylogeny--How a Tree Can Help

Characterize Early Life on Earth Eric A. Gaucher, James T. Kratzer and Ryan N. Randall

Cosmic Carbon Chemistry: From the Interstellar Medium to the Early Earth Pascale Ehrenfreund and Jan Cami

Origin and Evolution of the Ribosome George E. Fox

Planetary Organic Chemistry and the Origins of Biomolecules Steven A. Benner, Hyo-Joong Kim, Myung-Jung Kim, et al.

Mineral Surfaces, Geochemical Complexities, and the Origins of Life

Robert M. Hazen and Dimitri A. Sverjensky

Historical Development of Origins Research Antonio Lazcano
The Hadean-Archaean Environment Norman H. Sleep

An Origin of Life on Mars Christopher P. McKay

Primitive Genetic Polymers Aaron E. Engelhart and Nicholas V. Hud

Membrane Transport in Primitive Cells Sheref S. Mansy

The Origins of Cellular Life Jason P. Schrum, Ting F. Zhu and Jack W. Szostak

From Self-Assembled Vesicles to Protocells Irene A. Chen and Peter Walde

The Origin of Biological Homochirality Donna G. Blackmond

Earth's Earliest Atmospheres Kevin Zahnle, Laura Schaefer and Bruce Fegley

For additional articles in this collection, see http://cshperspectives.cshlp.org/cgi/collection/

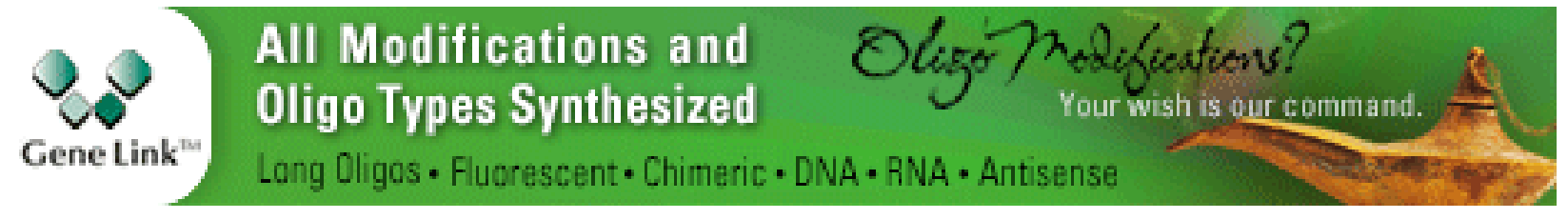

